\title{
Human (In)Security and Democracy in Central America
}

\section{Thomas O'Brien}

\section{Cranfield University at the Defence Academy of the United Kingdom}

\author{
t.obrien@cranfield.ac.uk
}

\begin{abstract}
Human security has increasingly shifted attention to the individual, while the state has become guarantor (or violator) of security given its role in governing the domestic environment. This paper examines how variations in regime forms influence security, pointing to the importance of political security in the wider human security framework. To illustrate the paper examines the nature of political security in Central America, a region with weakly democratised states and histories of political violence. The findings suggest a link between democracy and human security that is mediated by state capacity and the ability to control non-state violence against individuals.
\end{abstract}

Keywords: state capacity, contentious politics, political violence, authoritarian

\section{Introduction}

Human security has gained significant purchase in policy and academic spheres since it first emerged in 1994. Key to this has been a focus on the security of the individual, independent or alongside that of the state. Despite this apparent importance a number of critiques have been laid against the idea of human security and whether its breadth effectively undermines its ability to provide for the security of vulnerable populations. ${ }^{1}$ Events internationally also point to the difficulties of states in ensuring comprehensive human security. These pressures are further compounded when the state does not have the same degree of commitment to the security of its population. Authoritarian and democratic states vary considerably in their ability to guarantee the security of their populations. The absence of effective mechanisms for accountability in authoritarian states means that genuine human security threats may be 
suppressed or ignored in order to ensure the stability of the regime the picture in semiauthoritarian regimes is less clear.

In order consider the utility of human security and its application in situations of semiauthoritarian or weakly democratic regimes this paper examines the situation in Central America. This region suffered substantial political challenges during the $20^{\text {th }}$ century ranging from civil war to revolutionary change. ${ }^{2}$ Brockett notes that progressive movements that emerged from the 1960s:

faced great odds, from the intransigence of economic elites to harrassment and intimidation by both public and private security forces.... As nonviolent mass movements grew in size and contentiousness...states became more repressive, less so in Costa Rica and Honduras, much more so in Nicaragua, and horrifically so in El Salvador and Guatemala. ${ }^{3}$

While the levels of violence across the region have reduced substantially and a greater degree of political stability has been achieved there remain significant threats to the security of individuals. Weak state capacity and commitment to democracy in some of the states has meant that use of violence by the state has continued. ${ }^{4}$ These challenges are compounded by the flourishing of criminal enterprises in the gaps left by the state have presented direct threats to individuals and communities. ${ }^{5}$

This paper argues that human security needs to be reconsidered in order to enhance its contribution to a more comprehensive form of security. Specifically, within the seven areas of human security, it is argued that political security should be seen as a more overarching requirement under which the other forms reside. The aim is not to undermine the breadth of human security, but rather to facilitate recognition of a hierarchy. In the absence of political 
security the ability of individuals to express other forms of insecurity is significantly reduced, potentially leaving them unacknowledged. The remainder of the paper is divided into four sections. The first section considers the nature of human security before focusing on identifying the significant elements within political security. In the second section, the paper turns to examine the broad character of authoritarian and democratic ideal type political systems within the framework of state capacity. The third section outlines the features of contentious politics and how these can be viewed as expressions of human insecurity at the individual level. Finally, the paper sets out data on contentious politics (protest and violence) in the Central American countries alongside measures of democracy and state capacity to identify change over time.

\section{Positioning Political Security}

Human security places the individual at the core of questions of security. This contrasts with conventional views of security that see the state as the focus of security, thereby limiting opportunities to consider sources of security at the sub-national level. ${ }^{6}$ Clarifying the distinction, Pettman has argued that under human security "state security can be seen as a means to an end... [that of s]ecuring people". ${ }^{7}$ In making this shift it becomes essential to consider the interactions between individuals and groups that reside within the state and how they relate to the state itself. This view of security opens the practices of the state to observation and challenge from above and below. The move to focus on the individual mirrors the resurgent interest in civil society as a means of balancing formal state apparatus and expressing concerns within the population. ${ }^{8}$ In both cases the individual or group is given agency and recognition to challenge the established order where necessary. 
In defining human security the United Nations Development Programme (UNDP) Human Development Report identified:

two main aspects... first, safety from such chronic threats as hunger, disease and repression. And second... protection from sudden and hurtful disruptions in the patterns of daily life - whether in homes, in jobs or in communities. ${ }^{9}$

Within these broad themes seven specific areas were identified - economic, food, health, environmental, personal, community and political. This broad developmentalist view of human security has been characterised as 'freedom from want', fitting with the organisational focus of the UNDP. ${ }^{10}$ The broad view was also important in identifying the temporal variation in security threats, drawing a distinction between those that are chronic and sudden, reinforcing the need to develop capacity. The comprehensive scope of human security has led to claims that it is too broad to be meaningful. In an influential critique Paris argued that "[t]he study of causal relationships requires a degree of analytical separation that the notion of human security lacks." $" 11$ The challenge entailed in human security is that the complex nature of the security threats means that they are compounding, making the specification of dependent and independent variables difficult, if not impossible. ${ }^{12}$

In contrast to the broader view the 'freedom from fear' perspective argues for a narrower view, focusing on personal, community, and political security challenges that present direct physical threats to individuals and groups. This perspective is more closely aligned with conventional security approaches to security, holding that as long as individuals have the right to live free from the threat of physical harm human security will be guaranteed. ${ }^{13}$ In challenging this narrow understanding of human security, advocates argue that 'freedom from want' and 'freedom from fear' cannot be separated as factors identified in the broader 
concept act as catalysts and underlying drivers for threats to physical well-being. ${ }^{14}$ Human security therefore requires the untangling of a much more complex blend of interrelated factors than in conventional understandings of security, in turn leading to a more nuanced approach. ${ }^{15}$ This point is supported by Owen, who argues that:

by bringing the wide range of issues, data sets and knowledge of threats together, we facilitate the very type of interdisciplinary analysis needed to decipher the complex relations that make up our human security. ${ }^{16}$

Rather than simply attempting to deal with the manifestation of conflict, human security potentially opens the way to consider the underlying causes of conflict and find a more sustainable long-term solution that will prevent security threats re-emerging as frequently.

While these competing views both have merit, the character of the security contemporary threats that are emerging suggest that the broader perspective has more to offer. Viewing the provision of security from the perspective of the emerging field of complexity suggests that it is not useful to examine threats to the security of individuals as isolated from one another. Threat multipliers do not act as discreet entities but rather interact with one another leading to unexpected outcomes. ${ }^{17}$ Changes in the environment and the increasingly interconnected nature of the world system mean that it is necessary to view interactions as being part of an open system. ${ }^{18}$ Within this system the free flow of information about threats presents the greatest opportunity to identify and where possible provide remedies. This in turn brings the state back into the picture, acting as facilitator and guarantor of human security.

As pre-eminent actor in ensuring human security, the institutions of the state sit at the centre of the security structure. International institutions exist above the state, but are required to 
channel their interventions through, and seek the permission of, the state in order to operate. ${ }^{19}$ Sub-national bodies that reside within the state rely on it to provide institutional and regulatory supports that determine the scope of their operations and provide protection. ${ }^{20}$ Varying forms of human security place different requirements on the institutions responsible for guaranteeing security. The broader forms of insecurity captured in freedom from want entail significant complexity and identify the limits of the state to ensure security. In the

increasingly globalised world system, it is difficult for individual states to exercise control over factors impacting these forms of insecurity. While human security has shifted the focus from the state to the individual (as Pettman notes) this does not exempt the state from its responsibilities. Given the significance of the state in supporting (or undermining) the security of the individual it would seem to make sense to view political security as an important component in supporting the other forms of security through the facilitation of information flows and provision of protections for individuals expressing perceived in security. As such, human security should be conceptualised in the broad sense to encompass the full seven areas, but the relative overarching position of political security should be recognised.

\section{Limitations of Authoritarian and Democratic Political Systems}

Human security relies on the state providing guarantees about the safety and security of the individual. As noted above, political security can be therefore be seen as an important component in guaranteeing the other forms. When considering the maintenance of human security at the domestic level the state remains the primary actor. Discussing the position of the state Tadjbakhsh and Chenoy argue: 
unlike representatives of the civil society, NGOs and other groups, it represents the majority of people in a given territory, and this provides ultimate legitimacy, provided the majority is not predator to a minority, and that democratic institutions function properly. ${ }^{21}$

The willingness and desire of a particular state to ensure the security of its population depends very much on its driving motivations and ability to recognise signals from the population. The most substantial area of difference in this regard is between authoritarian and democratic regimes (recognising also states that occupy an intermediate gray zone ${ }^{22}$ ). The features of each prioritise the interests of a select group (authoritarian) or the broader population (democracy), which in turn significantly impacts the provision of human security.

The distinction between regime types is premised on the notion that democratic regimes will choose to prioritise the interests of the subject population over those of select elite actors. However, this assumes that the regime has the capacity and governance mechanisms in place to ensure security. If the regime lacks the ability to effectively manage its territory the likelihood of political security, and by association other forms of human security, is greatly reduced regardless of the intentions. Discussing the issue Sewell argues that:

Crucial to states' control over territory is policing - the surveillance of the activities of citizens and the use of coercion to enforce laws and maintain order... To be fully effective, the state's policing must cover the entire space of the territory. ${ }^{23}$

Policing in this sense refers to the broader ability of the state to effectively govern the territory under its control. This idea of control suggests the possession of formal capacity alongside less institutionalised governance instruments.

Capacity refers to the more institutionalised and quantifiable components of the state apparatus. In an important consideration of state capacity, Cummings and Nørgaard identified 
four key dimensions: ideational, political, technical, and implementational. ${ }^{24}$ These dimensions are considered below in order to frame the ability of states to ensure human security. The first dimension deals with issues of legitimacy, which as noted above is determined by the form of regime. The origins of a regime's legitimacy play an important role in determining its motivations and actions. Discussing the significance of legitimacy to the regime Brooker argues that it is essential in "establish[ing] the right to rule and the duty to obey". ${ }^{25}$ It has long been argued that authoritarian and democratic political systems rest on different bases of legitimacy. In democratic systems the requirement of the state to seek reelection periodically requires it to consider the views of its subject population; if it loses it will be replaced by a competing party (or coalition of parties). In this situation the institutions that support the conduct of the state are seen as the source of legitimacy, as the failure of a particular party does not signal a failure in the system as a whole.

By contrast, authoritarian regimes are forced to rely on narrower and potentially more fragile bases of legitimacy. The ability of a non-democratic regime to exercise control is generally supported by the use of force, but there is also often a search for some form of legitimacy. The closed nature of the authoritarian system means that the regime is unable to determine the level of true legitimacy within the population, with the risk that attempts to do so might destabilise it. The forms of legitimacy open to such regimes centre around four key mechanisms: legal basis, national interest, electoral, or ideological justification. ${ }^{26}$ The common features of legal, national interest and ideological bases are that they rely on the regime claiming to be acting on behalf of the interests of the state and its citizens, yet they rely on the views of those in power. The electoral route provides a slightly more sophisticated and complicated position. The drive towards democracy promotion has encouraged 
authoritarian states to hold elections in order to generate legitimacy domestically and internationally. However, as Levitsky and Way argue the increase in elections does not mean a shift in the nature of the regimes, as structural constraints are often organised to prevent meaningful opposition from emerging and also doing away with the need for blatant election theft. $^{27}$

Considering the make-up of the political dimension of state capacity Cummings and Nørgaard argue that it:

refers to what makes for an effective structure of governance, both horizontally (how individuals and departments work together internally within government) and vertically (how individuals and departments relate to the domestic and international community). ${ }^{28}$

This dimension is clearly shaped by the nature of the regime (authoritarian or democratic), but is also influenced by deeper relations between stakeholders both within and outside the formal state apparatus. Political capacity is significant in ensuring stable participation and oversight from external actors in order to ensure elite accountability. Comparing the governance capacity of authoritarian and democratic regime types, Bäck and Hadenius argue that democratic political systems possess greater levels of state administrative capacity, as they are able to integrate the views of stakeholders and adapt accordingly. ${ }^{29}$ By contrast, as Soroka notes in authoritarian systems negative feedback is restricted as "either the common good is not a priority, or there is a belief that the common good can be determined by a small group of individuals". 30

Turning to the form of governance or political capacity there are clear differences between the systems that suggest why democratic regimes are more able to adapt. Drawing on Bäck 
and Hadenius, Table 1 outlines the predominant mode of operation across the areas of administrative control. ${ }^{31}$ As the table suggests, authoritarian systems rely much more heavily on centralised, top-down and potentially rule-bound forms of administration. While this structure can potentially allow for decisions to be made more rapidly, the range of views that can be considered is likely to be significantly reduced. From the broader perspective on state capacity outlined above, this has the potential to weaken overall capacity through negative impacts on the perceived legitimacy of the state. The more decentralised and open character of democratic systems means that:

Social choices will be incremental changes from the status quo due to a large number of conflicting pressures, disjointed because there is no centralized coordination among choices in different parts of the system. ${ }^{32}$

This incremental change results in a situation where ideas are tested and refined in line with outcomes, leading to progression over time through social learning. Incrementalism is dependent on the relative strength of stakeholders and the priorities of administrative bodies.

Table 1: Administrative Control in Authoritarian and Democratic Systems

\begin{tabular}{|l|l|l|}
\hline & \multicolumn{2}{|c|}{ Regime Type } \\
\hline Sphere & Authoritarian & Democratic \\
\hline Policy Making & Centralised & Divided/decentralised \\
\hline Resources & Centralised & Divided/decentralised \\
\hline Implementation & Top-down & Cooperative \\
\hline Administrative oversight & Statutory & Public review \\
\hline
\end{tabular}

Source: Adapted from Bäck and Hadenius 2008, 14-16.

Technical and implementational dimensions of state capacity build on the base established by the core ideational and political dimensions. The technical dimension captures "the 
intellectual and organisational resources owned by a state... that may be brought to bear on the policy-making process so as to design coherent, viable and politically feasible policies."33 The range of resources that can be operationalised in support of policy development will be reduced in authoritarian political systems that limit opportunities for external input (as noted in Table 1 above). Finally, implementational capacity points to the ability of the state to carry out its programmed policy agenda. The top-down nature of the authoritarian system means that it is more prone to capture by special interests thereby "ensuring that debate remains at the level of interests rather than underlying and common values." ${ }^{34}$ Although democratic systems are subject to potential capture by special interests, the presence of public review will ensure that this is less likely.

The difference between authoritarian and democratic political systems is therefore quite clear. Rigidity within authoritarian systems means that they are less able to take on board concerns from within the subject population and are more susceptible to capture by special interests or groups within society. This threat is further amplified by the centralised structure of policymaking and resource control (as outlined in Table 1), which enable decisions to be made more rapidly, potentially amplifying potential harms. Though this section has drawn a distinction between authoritarian and democratic political systems, these should be seen as ideal-types. ${ }^{35}$ Most political regimes exist in a space that combines elements of each, for example democratic political regimes vary significantly in the degree to which they permit and engage with public participation. The point is that the strength of the tendency towards authoritarianism or democracy will have an impact on the nature of political security, and by implication other forms of human security. The receptiveness of more democratic regimes will allow for greater adaptability and responsiveness to perceptions of insecurity. 


\section{Recognising Expressions of (Political) Insecurity}

In addition to the formal institutions, it is also important to consider the role of quasi-state and non-state groups represented by civil society. These institutions exist relatively independent of the state, although they may rely on it for some form of financial support or legal framework. ${ }^{36}$ Quasi-state groups can pose an important challenge to security, particularly in the form of state backed militias or paramilitary organisations. ${ }^{37}$ These groups have the ability to challenge human security in a number of ways, both directly and indirectly. Direct challenges come from threats to personal and community security, particularly where the state uses them as a proxy for more conventional forces. They can also have an indirect impact on human security through the distortion of economic markets or the availability of food resources. Although the impacts vary with context, it is important to note that the presence of such groups, either for or against the state, can impact different aspects of human security. ${ }^{38}$

Non-state groups ranging from communal and religious institutions in the broad sense as well as more formalised non-governmental organisations (NGO) also have an important role to play in both facilitating and challenging human security. Where the state is unable or unwilling to ensure the provision of basic services these groups can provide assistance, for example in the provision of medical support or food distribution. ${ }^{39}$ Their role will be determined by the need on the ground, and also the willingness of the state to allow their participation. In non-democratic states non-governmental activity is limited and highly restricted, often leading to situations where independent groups are prevented from operating. ${ }^{40}$ In addition, communal or religious institutions can in themselves present a threat 
to human security, where membership of a particular community is used to introduce discord and challenge the security of non-affiliated populations, potentially leading to community and personal security threats. ${ }^{41}$

While states set the limits of accepted behaviours, the location of these boundaries and the ability to enforce them is determined by the character of the state. Addressing this issue, Tilly and Tarrow point to the combination of state capacity and the level of democracy in each case. With regard to the level of democracy, they argue that:

In mainly democratic regimes, the repertoire of contention leans towards peaceful forms of contention that intersect regularly with representative institutions and produce social movement campaigns; in mainly authoritarian regimes, the repertoire leans towards lethal conflicts and tends to produce religious and ethnic strife, civil wars and revolutions. ${ }^{42}$

The range of contentious activities adopted by claim-makers is shaped therefore by the character of the regime and the range of permitted actions. In the absence of the right to undertake non-violent protest actions, opponents will be more likely to adopt violence to achieve their goals. The extent of state capacity further complicates this picture by raising questions regarding the ability of the state to enforce the limits it has established. Where the state lacks the institutions and authority (capacity) to control its territory, the opportunities for mobilization by non-state actors are greater. This in turn presents potential challenges to human security, as the state does not have the ability to fulfil its role as guarantor of security.

As noted, human security is shaped by the character of the political system and the willingness or otherwise of the state to act to protect the subject population. Contentious actions within the population can be seen in this context as an attempt to express insecurity in 
the absence of effective regularised channels to have these concerns heard. The form of the political system does much to determine the likelihood of contentious actions erupting, as participants calculate the costs of action and inaction. ${ }^{43}$ During periods of political instability the ability to calculate these costs is reduced, as the likely actions of the state are less clear. This next section considers the costs of action in the case of Central America, asking to what extent political security (and human security generally) was undermined by the lack of capacity of the states in the region and the lingering authoritarian structures and legacies.

\section{Insecurity, State Capacity and Democracy in Central America ${ }^{44}$}

Central America saw significant upheaval across its history, influenced to a large extent by its regional location and resulting geopolitical pressures. The region saw revolutions and extensive deadly civil wars. This pattern changed during the 1980s and the early 1990s as the wave of democratisation reached the region and the end of the Cold War reduced ideological tensions. ${ }^{45}$ Since this time there has been a degree of political stability, with changes in political regime taking place with lower levels of violence and more recently the 'pink tide' that has swept Latin America bringing in left-leaning governments. ${ }^{46}$ While this change has reshaped the character of the region, there are significant variations in the levels of political freedom and violence. In order to understand the significance of democracy for the provision of human security this section considers variations across the region during the period of increased stability (1990-2004).

The trend of democratisation is most clearly illustrated in the changes in classification of the regimes over the period. In 1990 two of the regimes were classified as 'free' and four were 'partially free', by 2004 this had changed minimally to three free and three partially free. ${ }^{47}$ 
This suggests that in contrast with many world regions during this period, the wave of democratisation had limited impact on Central America. Two states (El Salvador and Panama) joined Costa Rica in the 'free' category, whereas Honduras regresssed to join Guatemala and Nicaragua in the 'partially free' group. These changes are significant, as semiauthoritarian regimes have been identified as being less stable, attempting to use democratic tools to maintain order and control. ${ }^{48}$ Bäck and Hadenius also find that state capacity falls during periods of democratisation, as the rules of the game are redefined. ${ }^{49}$

The challenges of reduced state capacity as noted above have the potential to limit the ability of the state to ensure political security. This pattern was seen in Central America, as represented in Figure 1 below, considering the relationship between violence used by the state and broader society more generally. ${ }^{50}$ The figure shows that the level of violence used by non-state actors fell dramatically between 1990 and 1994, maintaining a generally downward trajectory (with the exception of 1996). In contrast, levels of state violence fell but maintained levels that were consistently higher over the period, with surges in the late 1990s and at the end of the series. Levels of protest were lower overall, but these also saw a steady decline over the period (with state initiated protests being minimal throughout). Much of the initial decline in civil violence was the result of the end of the civil war in El Salvador and the move towards democracy in the early 1990s. ${ }^{51}$

Figure 1: Civil and State Protest and Violence in Central America (1990-2004) 


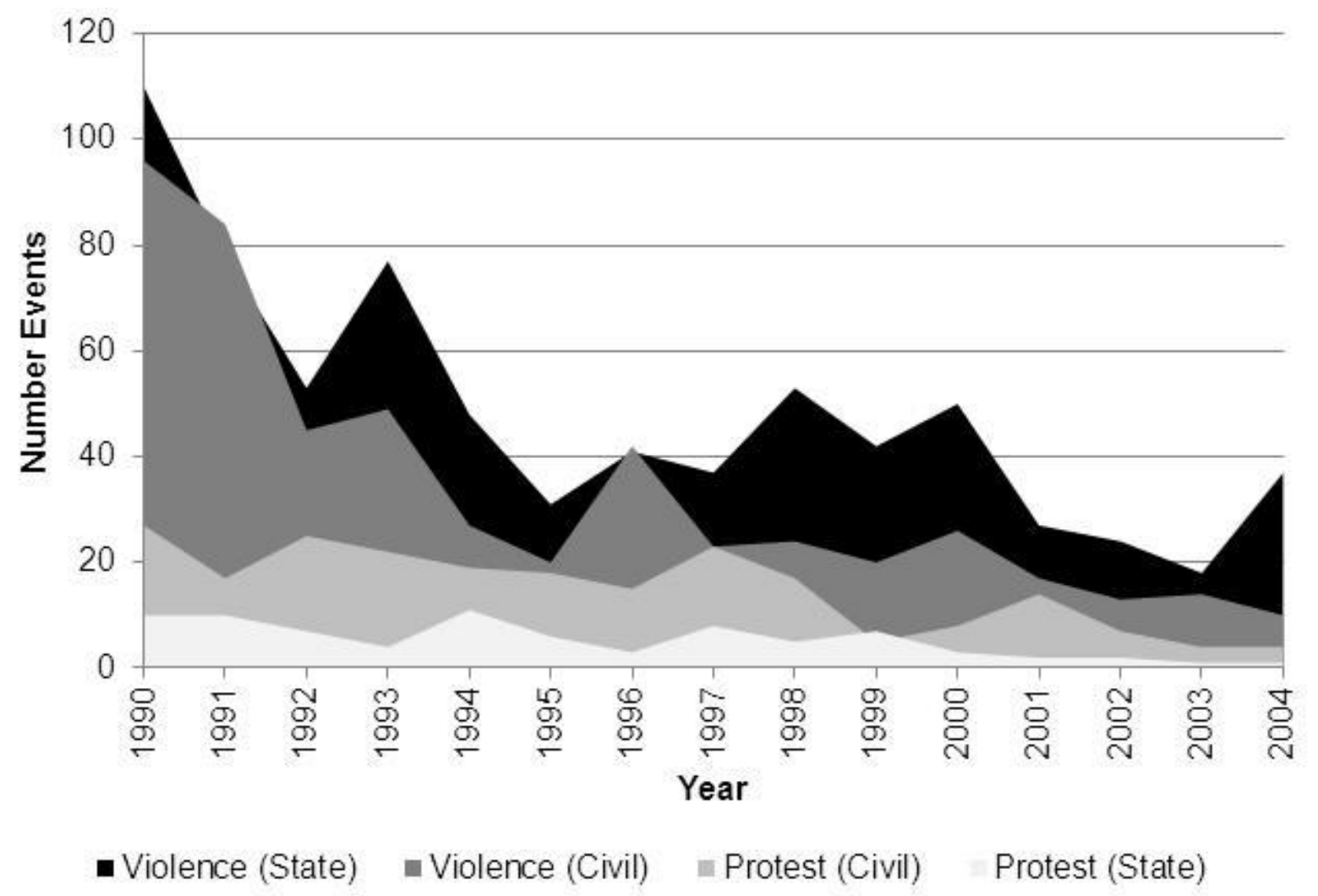

Source: World Handbook of Political Indicators (WHIV)

https://sociology.osu.edu/worldhandbook [accessed 28-07-14]

Turning to the specific forms of protest and violence perpetrated the sources of the differences can be further identified. Data on protest and violence presented in Table 2 show significant variation in the range of actions undertaken. ${ }^{52}$ Protest actions clustered around standard repertoires of contentious politics - marches, rallies, demonstrations, obstructions and strikes. As noted above, state protests were much lower and can be seen to focus mainly on rallies in support of the regime. By contrast, forms of violence were much more varied and greater in number. Both state and civil actors made extensive use of armed conflict, linked to the civil wars that characterised the preceding decade. The most numerous form of violence used by the state was that of physical assault, making up almost half of all use of violence by 
the state. Civil actors also made use of physical violence along with hostage taking and kidnap with some degree of frequency. These forms of violence are likely targeted against the individual (as with assassination), demonstrating clearly the absence of political security, as individuals are threatened with violence by the state and civil actors alike.

Table 2: Total Protest and Violent Events in Central America (1990-2004)

\begin{tabular}{|c|c|c|c|c|}
\hline Group & Action & Civil & State & Unknown \\
\hline \multirow{7}{*}{ Protest } & Protest Altruism & 6 & 1 & 0 \\
\hline & Protest Demonstration & 25 & 4 & 4 \\
\hline & Protest March & 42 & 3 & 0 \\
\hline & Protest Obstruction & 22 & 6 & 1 \\
\hline & Protest Defacement & 13 & 0 & 1 \\
\hline & Rally Support & 42 & 48 & 0 \\
\hline & Strikes \& Boycotts & 75 & 18 & 7 \\
\hline \multirow{16}{*}{ Violence } & Missile Attack & 0 & 1 & 8 \\
\hline & Assassination & 9 & 16 & 1 \\
\hline & Beating & 1 & 4 & 1 \\
\hline & Crowd Control & 6 & 30 & 0 \\
\hline & Corporal Punishment & 5 & 6 & 0 \\
\hline & Coups and Mutinies & 1 & 5 & 0 \\
\hline & Artillery Attack & 24 & 9 & 58 \\
\hline & Hostage Taking and Kidnap & 59 & 43 & 0 \\
\hline & Hijacking & 6 & 5 & 0 \\
\hline & Torture & 7 & 12 & 0 \\
\hline & Physical Assault & 70 & 367 & 39 \\
\hline & Small Arms Attack & 193 & 117 & 19 \\
\hline & Armed Action & 104 & 103 & 20 \\
\hline & Riot & 24 & 7 & 14 \\
\hline & Sexual Assault & 1 & 1 & 0 \\
\hline & Vehicle Bombing & 0 & 0 & 1 \\
\hline TOTAL & & 735 & 806 & 174 \\
\hline
\end{tabular}

Source: World Handbook of Political Indicators (WHIV)

https://sociology.osu.edu/worldhandbook [accessed 28-07-14]

When considering levels of governance across the states the differences become more apparent and may suggest sources of insecurity. Costa Rica and Panama had governance 
scores (see Table 3) that were higher and also saw lower levels of violence, including that perpetrated by the state. ${ }^{53}$ At the same time, El Salvador saw its governance score increase marginally, while levels of violence continued a downward trend. The remaining three states (Guatemala, Honduras, and Nicaragua) had consistently lower governance scores and were classified as partially free for much or all of the period. These states saw levels of political violence (state and civil) that were higher and more variable in their pattern. ${ }^{54}$ This variation would seem to fit with the notion of instability associated with semi-authoritarian regimes, as actors struggle among themselves to gain and maintain control.

Table 3: Levels of Violence and Governance in Central America

\begin{tabular}{|l|c|c|c|c|c|c|c|c|c|}
\hline & \multicolumn{3}{|c|}{ State Violence* } & \multicolumn{3}{c|}{ Civil Violence } & \multicolumn{3}{c|}{ Governance } \\
\hline & $\mathbf{1 9 9 6}$ & $\mathbf{2 0 0 0}$ & $\mathbf{2 0 0 4}$ & $\mathbf{1 9 9 6}$ & $\mathbf{2 0 0 0}$ & $\mathbf{2 0 0 4}$ & $\mathbf{1 9 9 6}$ & $\mathbf{2 0 0 0}$ & $\mathbf{2 0 0 4}$ \\
\hline Costa Rica & 3 & 6 & 3 & 2 & 1 & 1 & 62.38 & 63.02 & 60.42 \\
\hline El Salvador & 12 & 6 & 3 & 7 & 3 & 2 & 39.39 & 43.04 & 46.65 \\
\hline Guatemala & 14 & 15 & 10 & 12 & 6 & 8 & 38.32 & 39.67 & 39.08 \\
\hline Honduras & 5 & 7 & 6 & 4 & 4 & 2 & 35.14 & 38.33 & 39.06 \\
\hline Nicaragua & 13 & 9 & 1 & 8 & 5 & 0 & 41.15 & 38.44 & 41.13 \\
\hline Panama & 3 & 3 & 3 & 2 & 5 & 1 & 50 & 53.09 & 51.53 \\
\hline
\end{tabular}

* State Violence and Civil Violence figures report the average of the four years up to and including the year listed.

Source: Worldwide Governance Indicators www.govindicators.org [Accessed 10 July 2012] and World Handbook of Political Indicators (WHIV) https://sociology.osu.edu/worldhandbook [accessed 28-07-14]

Together these data present a complicated picture of political security in Central America. It is clear that the democratic states in the region saw lower levels of political violence, represented clearly by the steady decline in El Salvador. The semi-authoritarian regimes of Guatemala, Honduras and Nicaragua by contrast saw more erratic patterns, with state 
violence rising and falling over the period. In all of the cases civil violence remained consistently lower than state violence for almost the whole period (as captured for the region as a whole in Figure 1). The period considered also saw some improvements in state capacity (as represented in Table 3), although these were again stronger in the states identified as democratic. The pattern across the region suggests that the democratising states are more able to maintain lower levels of violence and ensure greater security and stability for their populations, focusing on political security.

Human security relies on state capacity to manage the totality of its territory and also to mediate between competing actors. The pattern of violence and protest shows that while violence has decreased the state remains a key perpetrator. It also appears that weak state capacity (see Table 3) is linked to higher levels of state violence. Further to this, the reliance of authoritarian states on centralised top-down policy mechanisms reduce opportunities for feedback on the policies and practices of the regime. ${ }^{55}$ The findings suggest that in order to ensure the broader conception of human security can be achieved a stronger focus on political security and the nature of the state must be addressed. The reliance of democratic states on support from the population ensures that where capacity exists manifestations of insecurity will be treated.

\section{Conclusion}

Human security has shifted the focus of attention from ensuring the security of the state to that of the individual. Despite the reconceptualisation of security the state remains the key guarantor of security. Within the broader approach to human security there is significant diversity, raising questions about the utility of the concept. This paper has argued that while 
the breadth does not undermine the concept, work is required to refine the application. Focusing on political security as an overarching component of human security can grant greater analytical and practical purchase, while not invalidating the broader 'freedom from want' understanding. Subsequent forms of human security (food, economic, health, economic, personal, and community) are dependent on stability and certainty that is enabled by political security.

The form of regime determines the likelihood of political security being achieved. Authoritarian regime focus on the views and interests of unaccountable elites militates against consistent political security. While such regimes can technically provide such security the lack of feedback mechanisms prevents adjustments necessary to account for changing contexts. State capacity provides an additional layer of complexity, with weak capacity undermining the maintenance of all forms of human security. These tensions are apparent in the case of Central America. The period considered in this paper (1990-2004) began at the end of a series of civil wars and extensive political violence across the region. The countries in the region that had managed to maintain or achieve democracy saw declines (sometimes dramatic) in levels of political violence (civil and state). The semi-authoritarian regimes by contrast saw levels of political violence fluctuate, with state violence remaining consistently higher than civil violence. These findings reinfoce the importance of political security within the wider understandings of human security.

\footnotetext{
${ }^{1}$ For an early and strident critique see Roland Paris, "Human Security: Paradigm Shift or Hot Air?" International Security, 26 (2001): 87-102.
} 
${ }^{2}$ Fabrice Lehoucq, The Politics of Modern Central America: Civil War, Democratization, and

Underdevelopment (Cambridge: Cambridge University Press, 2012).

${ }^{3}$ Charles D. Brockett, Political Movements and Violence in Central America (Cambridge: Cambridge University Press, 2005), 1.

${ }^{4}$ José Miguel Cruz, "Criminal Violence and Democratization in Central America: The Survival of the Violent State," Latin American Politics and Society 53 (2011): 1-33.

${ }^{5}$ Orlando J. Pérez, “Gang Violence and Insecurity in Contemporary Central America,” Bulletin of Latin American Research 32 (2013): 217-234.

${ }^{6}$ Barry Buzan and Lene Hansen, The Evolution of International Security Studies (Cambridge: Cambridge University Press, 2009).

${ }^{7}$ Ralph Pettman, "Human Security as Global Security: Reconceptualising Strategic Studies”, Cambridge Review of International Affairs 18 (2005): 137-150, 145.

${ }^{8}$ Neera Chandhoke, “The 'Civil' and the 'Political' in Civil Society”, Democratization 8 (2001): 1-24.

${ }^{9}$ United Nations Development Programme, Human Development Report 1994 (New York: Oxford University Press, 1994), 23.

${ }^{10}$ Amitav Acharya, "Human Security," in The Globalization of World Politics: An Introduction to International Relations $\left(4^{\text {th }}\right.$ ed), ed. John Baylis, Steve Smith, and Patricia Owens (Oxford: Oxford University Press, 2008), 490-505.

${ }^{11}$ Paris, "Human Security", 93.

${ }^{12}$ Pauline Ewan, "Deepening the Human Security Debate: Beyond Politics of Conceptual Clarification," Politics 27 (2007): 182-189.

${ }^{13}$ Barry Buzan, "Rethinking Security after the Cold War," Cooperation and Conflict 32 (1997): 5-28.

${ }^{14}$ Yukiki Nishikawa, "Human Security in Southeast Asia: Viable Solution or Empty Slogan?” Security Dialogue 40 (2009): 213-236.

${ }^{15}$ Ryerson Christie, “Critical Voices and Human Security: To Endure, To Engage or to Critique?” Security Dialogue 41 (2010): 169-190.

${ }^{16}$ Taylor Owen, "Human Security - Conflict, Critique and Consensus: Colloquium Remarks and a Proposal for a Threshold-Based Definition,” Security Dialogue 35 (2004): 373-387, 380. 
${ }^{17}$ Robert Geyer and Samir Rihani, Complexity and Public Policy: A New Approach to $21^{\text {st }}$ Century Politics, Policy and Society (London: Routledge, 2010).

${ }^{18}$ Robert Geyer, "Beyond the Third Way: The Science of Complexity and the Politics of Choice," British Journal of Politics and International Relations 5(2003): 237-257.

${ }^{19}$ Thomas Legler and Thomas Kwasi Tieku, "What Difference Can a Path Make? Regional Democracy Promotion Regimes in the Americas and Africa", Democratization 17 (2010): 465-491.

${ }^{20}$ Chandhoke, "The 'Civil' and the 'Political"”.

${ }^{21}$ Shahrbanou Tadjbakhsh and Anuradha M. Chenoy, Human Security: Concepts and Implications (London: Routledge, 2007), 166.

${ }^{22}$ See Steven Levitsky and Lucan A. Way Competitive Authoritarianism: Hybrid Regimes after the Cold War (Cambridge: Cambridge University Press, 2010).

${ }^{23}$ William H. Sewell, Jr., "Space in Contentious Politics", in Ronald R. Aminzade, Jack A. Goldstone, Doug McAdam, Elizabeth J. Perry, William H. Sewell, Jr., Sidney Tarrow and Charles Tilly (eds.), Silence and Voice in the Study of Contentious Politics (Cambridge: Cambridge University Press, 2001), 68.

${ }^{24}$ Sally N. Cummings and Ole Nørgaard, "Conceptualising State Capacity: Comparing Kazakhstan and Kyrgyzstan,” Political Studies 52 (2004): 685-708.

${ }^{25}$ Paul Brooker, Non-Democratic Regimes: Theory, Government and Politics (Basingstoke: Palgrave, 2000), 104.

${ }^{26}$ Brooker, Non-Democratic Regimes.

${ }^{27}$ Levitsky and Way, Competitive Authoritarianism.

${ }^{28}$ Cummings and Nørgaard, "Conceptualising State Capacity”, 688.

${ }^{29}$ Hanna Bäck and Axel Hadenius, "Democracy and State Capacity: Exploring a J-Shaped Relationship," Governance 21 (2008): 1-24.

${ }^{30}$ Stuart N. Soroka, Negativitty in Democratic Politics: Causes and Consequences (Cambridge: Cambridge University Press, 2014), 116.

${ }^{31}$ Bäck and Hadenius, "Democracy and State Capacity”, 14-16. 
${ }^{32}$ John Dryzek, Rational Ecology: Environment and Political Economy (Oxford; Basil Blackwell, 1988), 118. See also: R. Kent Weaver, "Paths and Forks or Chutes and Ladders? Negative Feedbacks and Policy Regime Change," Journal of Public Policy 30 (2010): 137-62; and Soroka, Negativity in Democratic Politics, Chapter 7.

${ }^{33}$ Cummings and Nørgaard, "Conceptualising State Capacity”, 688.

${ }^{34}$ Dryzek, Rational Ecology, 122.

${ }^{35}$ Weber defined the ideal type as a "construction of certain elements of reality into a logically precise conception", which can aid comparison by identifying forms between which the cases being considered are located. H. H. Gerth and C. Wright Mills (eds.) From Max Weber: Essays in Sociology (London: Routledge, 1964), 59-60.

${ }^{36}$ Chandhoke, "The 'Civil' and the 'Political".

${ }^{37}$ See: Navin A. Bapat, "Understanding State Sponsorship of Militant Groups,” British Journal of Political Science 42 (2011): 1-29.

${ }^{38}$ Abdel-Fatau Musah, "Privatization of Security, Arms Proliferation and the Process of State Collapse in Africa," Development and Change 33 (2002): 911-933.

${ }^{39}$ Richard Batley and Claire McLaughlin, "Engagement with Non-State Service Providers in Fragile States: Reconciling State-Building and Service Delivery,” Development Policy Review 28 (2010): 131-154. Julie Hearn, “The 'NGO-isation' of Kenyan Society: USAID and the Restructuring of Health Care," Review of African Political Economy 25 (1998): 89-100.

${ }^{40}$ Christopher Heurlin, "Governing Civil Society: The Political Logic of NGO-State Relations under Dictatorship," Voluntas 21 (2010): 220-239.

${ }^{41}$ Charles Tilly, The Politics of Collective Violence (Cambridge: Cambridge University Press, 2003).

${ }^{42}$ Charles Tilly and Sidney Tarrow, Contentious Politics (Boulder: Paradigm Press, 2007), 161.

${ }^{43}$ Jack A.Goldstone and Charles Tilly, "Threat (and Opportunity): Popular Action and State Response in the Dynamics of Contentious Action." In Silence and Voice in the Study of Contentious Politics, edited by Ronald R. Aminzade, Jack A. Goldstone, Doug McAdam, Elizabeth J. Perry, William H. Sewell, Jr., Sidney Tarrow, and Charles Tilly (eds.) (Cambridge: Cambridge University Press, 2001), 51-88.

${ }^{44}$ Central America is defined in this paper as including: Costa Rica, El Salvador, Guatemala, Honduras, Nicaragua and Panama. Belize is excluded due its distinct colonial history and recent independence. For a useful 
summary of the situation in Belize see: Mark Nowottny, "“No Tyrants Here Linger': Understandings of Democracy in Modern Belize," MSc Thesis, Institute for the Study of the Americas (2007). http://sasspace.sas.ac.uk/1131/1/Nowottny_Mark-notyrantsherelinger.pdf [Accessed 27-7-14].

${ }^{45}$ See: Samuel P. Huntington, The Third Wave: Democratization in the Late Twentieth Century. (Norman: University of Oklahoma Press, 1993).

${ }^{46}$ Barry Cannon and Mo Hume, “Central America, Civil Society and the 'Pink Tide': Democratization or Dedemocratization?" Democratization 19 (2012): 1039-64.

${ }^{47}$ Freedom House http://www.freedomhouse.org/ [accessed 29 October 2013].

${ }^{48}$ Levitsky and Way, Competitive Authoritarianism.

49 Bäck and Hadenius, "State Capacity and Democratisation".

${ }^{50}$ This data is drawn from the World Handbook of Political Indicators (WHIV) which uses an automated coding tool to capture events recorded in Reuters news stories. World Handbook of Political Indicators (WHIV) https://sociology.osu.edu/worldhandbook [accessed 28-07-14]. For a comparison of WHIV with competing data sources see: Jesse Hammond and Nils B. Weidmann, “Using Machine-Coded Event Data for the Micro-Level Study of Political Violence," Research and Politics July-September (2014): 1-8.

${ }^{51}$ See: Brockett, Political Movements and Violence in Central America.

${ }^{52}$ Table 2 also includes actions by actors where it is unclear whether they can be classified as civil or state.

${ }^{53}$ Data reported in the table are from the World Bank Worldwide Governance Indicators. The governance score reported includes the following categories: Voice and Accountability; Government Effectiveness; Regulatory Quality; Rule of Law; and Control of Corruption. The category Political Stability and Absence of

Violence/Terrorism is excluded, as inclusion would effectively involve double counting. The figures are derived by transforming the data from each category into a five point scale, adding these together and then calculating the position of the overall score relative to a perfect score (100\%). Worldwide Governance Indicators www.govindicators.org [Accessed 10 July 2012]

${ }^{54}$ As Figure 1 shows, the absolute levels of violence declined significantly during the period, meaning that the number of events in the latter three countries were not significantly higher overall.

${ }^{55}$ Bäck and Hadenius, "Democracy and State Capacity". 